\title{
Analysis of the energy potential of municipal solid waste for the thermal treatment technology development in Poland
}

\author{
Katarzyna Midor ${ }^{1, *}$, and Karolina Jąderko ${ }^{2}$ \\ ${ }^{1}$ Silesian University of Technology, Faculty of Organisation and Management, Institute of Production \\ Engineering, ul. Roosevelt 26, 41-800 Zabrze, Poland \\ 2Ekologia Przedsiębiorczość Innowacje Spółka z o.o., ul. Kuhna 17, 42-256 Olsztyn k/Częstochowy, \\ Poland
}

\begin{abstract}
The problem of overproduction of waste has been a local issue for many years. Since the new environment law came into effect, the current approach to waste management has changed significantly. The accessible technological possibilities of thermal waste treatment with the energy recovery set a new area of research over the process of choosing effective and rational way of calorific waste management. The objective of this article is to provide assessment results of the analysed energy potential in waste management system in the form of calorific waste stream. In includes all the activities and actions required to manage municipal solid waste from its inception to its final disposal i.e. collection, transport, treatment and disposal. The graphical representation of waste flow indicates the lost opportunities of waste energy recovery. Visual research method was supported and founded on value stream mapping. On the basis of the results were presented the directions of further improvement of calorific waste stream mapping for the purposes of implementation the thermal treatment technology in the selected waste management region.
\end{abstract}

\section{Introduction}

Due to the growing interest in the use of wastes for energy production, tools for effective management of a stream of high-calorie waste. New trends in waste management such as recycling logistics or ecologicstics cause a dynamic development of tools for assessing and analysing streams of combustible waste.

The ecological concept of logistics in a waste management system allows us to not only integrate processes, but also improve the flow of waste. In light of this approach managing a stream of waste is aimed at finding optimal solutions which take into account a number of conditions that minimise the negative effects on the environment and society, but also affecting its economic efficiency.

Effective and efficient transposition of logistics onto the field of waste management causes the practical use of tools from this area streamlines the flow of waste from the place of their creation to the place where they are ultimately managed. This article directs

${ }^{*}$ Corresponding author: katarzyna.midor@polsl.pl 
attention to the possibility of using value stream mapping in high-calorie waste management. The effect of this work is an attempt at illustrating the flow of caloric waste in a waste management system.

According to the initial concept, value stream mapping is a tool used for developing a complete method of flow management in a production system. Using the right symbols, it allows us not only to visualise the processes, but most importantly notice and eliminate wastage [1-4]. Using the value stream mapping tool we must first and foremost understand what a value is in the system. In the case of waste management, we should look for values in the properties of wastes that allow for their effective reuse. Waste recycling as the most ecological form of their management is based on the wastes' energetic and material properties, which determine the choice of an effective processing method.

\section{Methodology}

One of the aims of the research was an attempt at transposing a selected production engineering tool onto the area of waste management. Due to the cognitive and analytical nature of the research, the study was carried out in the following stages:

1. Choosing a regional waste management system and identifying the waste removal chain.

2. Analysis of the waste management system, especially the high-calorie waste stream.

3. Drawing up and analysing the current state map, and presenting the proposed changes and improvements

\subsection{Choosing a regional waste management system and identifying the waste removal chain}

The Silesian Voivodeship has been divided into four regions in terms of waste management. This division is justified by the amount of waste produced as well as the total efficiency of the already existing and planned waste management facilities. Waste logistics within a waste management region encompasses primarily such waste streams as:

- mixed municipal solid waste;

- remains from the sorting of municipal solid waste and mechanical-biological municipal waste processing if they are intended for storage;

- green wastes, which, according to the law, must be processed within the region in designated regional waste processing plants. An exception to this are supra-regional plants which are supposed to be incineration plants that allow for thermal processing of the wastes with energy recovery.

Due to the research goal set, the $2^{\text {nd }}$ Municipal Waste Management Region (MWMR 2) was chosen, characterised by the biggest population and, therefore, the largest amount of municipal solid waste produced among the regions.

The quantitative-qualitative analysis of the municipal waste collected in the MWMR 2 was conducted on the basis of borough reports on the realisation of waste management tasks for 2014. Table 1 presents the amount of municipal waste collected that was subjected to the particular management processes according to the recovery and disposal process list listed in the Waste Management Act (Journal of Laws (Dz.U.) 2013 item 21).

The boroughs' reports show that in $2014131426.8 \mathrm{Mg}$ of waste was disposed, which amounted to $16 \%$ of all the municipal solid waste collected, and the remaining $84 \%$, i.e. $705929.9 \mathrm{Mg}$ of waste was recycled. Worth noting are the R12 and R13 recycling processes which accounted for $72 \%$ of the waste treated. Taking into account the fact that the R12 process, as defined by the current law [6-8], pertains to the exchange of wastes in 
order to treat them using any of the processes from items $\mathrm{R} 1$ - R11, and the R13 process to the storage of wastes prior to any of the processes enumerated in items R1 - R12 (excluding the initial storage prior to collection), we should assume that these processes can cause a decrease in value - both material and energetic.

Table 1. Municipal waste management in MWMR 2.

\begin{tabular}{|c|c|}
\hline Method of management of the municipal waste collected & $\begin{array}{c}\text { Mass } \\
\text { [thous. Mg] }\end{array}$ \\
\hline D10 - Waste disposal process - on-land thermal treatment & 10.4 \\
\hline $\begin{array}{c}\text { D13 - Waste disposal process - blending or mixing prior to submission to any of the } \\
\text { D 1 to D 12 }\end{array}$ & 34454.79 \\
\hline $\begin{array}{c}\text { D5 - Waste disposal process - storage in specially designed landfills (e.g. placement } \\
\text { into lined discrete cells, capped and isolated from one another and the environment, } \\
\text { etc.) }\end{array}$ & 84042.98 \\
\hline $\begin{array}{c}\text { D8 - Waste disposal process - biological treatment not specified in another item } \\
\text { resulting in the formation of final compounds or mixtures which are disposed of using } \\
\text { any of the processes enumerated in items D1-D12 }\end{array}$ & 12954.63 \\
\hline $\begin{array}{c}\text { R1 - Waste recycling process - use mainly as a fuel or other means of energy } \\
\text { production }\end{array}$ & 12.3 \\
\hline $\begin{array}{c}\text { R10 - Waste recycling process - on-land treatment resulting in benefit to agriculture or } \\
\text { environmental improvement }\end{array}$ & 10144.1 \\
\hline $\begin{array}{c}\text { R12 - Waste recycling process - exchange of wastes in order to treat them using any of } \\
\text { the processes enumerated in items R1 - R11 }\end{array}$ & 597311.98 \\
\hline $\begin{array}{c}\text { R13 - Waste recycling process - storage of wastes prior to any of the processes } \\
\text { enumerated in items R1 - R12 (excluding initial storage prior to collection) }\end{array}$ & 8077.03 \\
\hline $\begin{array}{c}\text { R3 - Waste recycling process - recycling or regeneration of organic substances which } \\
\text { are not used as solvents (including composting and other biological processing) }\end{array}$ & 56278.04 \\
\hline R4 - Waste recycling process - recycling or recovery of metals and metal compounds & 13.28 \\
\hline R5 - Waste recycling process - recycling or recovery of other non-organic materials & 34093.06 \\
\hline R9 - Waste recycling process - oil re-refining or other reuses of oil & 0.07 \\
\hline Total & $\mathbf{8 3 7 3 9 2 . 6 6 3}$ \\
\hline
\end{tabular}

Source: own elaboration based on [5]

\subsection{Itemising the streams of high-calorie waste}

The characteristics of municipal solid wastes, which can potentially become an energetic resource, depends on several factors. These include: the type of development, saturation of the area with non-residential buildings (including business premises), as well as the technical furnishings of the buildings and their heating $[9,10]$. Equally important to the composition of the wastes are such elements as: affluence of the inhabitants, season, backyard green waste composters, and selective collection of recyclable waste conducted by the inhabitants. These and other factors affect the morphological composition of municipal solid waste and, consequently, their net caloric value. Therefore, the material composition of waste is connected with its fuel characteristics. Each of the constituents, when studied separately, is characterised by such properties as [10,11]:

- specific dampness;

- organic substance content;

- gross caloric value.

Separating the properties of wastes enables us to classify them into a group of combustible wastes, which are the input of the R1 thermal treatment process [12].

Quantitative analysis of the waste management system takes into account the total amount of waste collected within the boroughs which belong to MWMR 2 in 2014, 
detailing the codes of caloric wastes (Table 2) including paper, plastic, rubber, textile, wood waste, as well as mixed waste 1912 12, 2003 01, which are subject to a separate analysis. This division is justified by the need to develop a separate methodology for the analysis of caloric properties of mixed wastes (i.e. 1912 12, 200301 ). In practice it is assumed that the ballast from processing 191212 wastes is $50 \%$. This fraction, constituting the leftovers from the sorting process, is a high-calorie, problematic ballast deposited into landfills which simultaneously presents a large, unused energetic potential suitable for thermal processing. The effect of this study are data contained in Table 2.

Table 2. Juxtaposition of wastes with energetic potential in Region 2.

\begin{tabular}{|c|c|c|}
\hline Code & Group, subgroup and types of waste & $\begin{array}{c}\text { Mass [Mg] } \\
\text { in 2014 }\end{array}$ \\
\hline 15 & Waste packaging; absorbents, wiping cloths, filter materials and protective clothing \\
not otherwise specified
\end{tabular}

Source: [5] 


\section{Analysis of the energetic potential of municipal wastes}

The research results presented indicate that separating caloric waste from the municipal waste stream allows us to present the energetic potential of wastes collected in the waste management region subject to this study.

Transposing the value stream map commonly used for production processes allows for presenting the problem and exposing the value, which, in this case, is the caloric value of the collected wastes. Figure 1 is the result of an attempt at organising the data gathered.

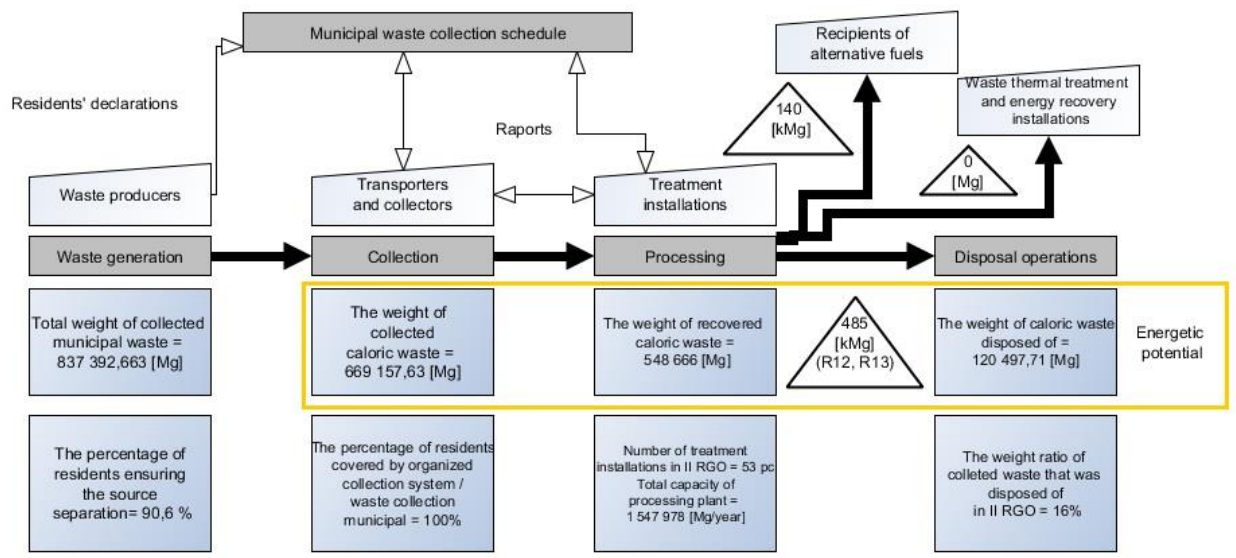

Fig. 1. Value stream map of the waste management system. Source: own elaboration based on [5].

The analysis of caloric stream flow in the waste management system of the $2^{\text {nd }}$ MWMR indicates that the lack of a thermal municipal waste processing facility causes wastage in form of unused energetic potential of the collected waste. The scale of this wastage has been calculated based on the accepted division of energetic potential presented in [5] (Fig. 2):

- theoretical potential including all the caloric municipal wastes collected in a given region;

- available potential, a part of the theoretical potential reduced by the mass of caloric wastes subjected to recycling and recovery (R1-R11) and including the disposal processes - D as well as other recycling processes, i.e. R12 and R13, which pertain to waste exchange and storage;

- technical potential, a part of the available potential that has been reduced by the share of problematic ballast from the sorting process of wastes with the codes 1912 12 and 200301 , which, according to the accepted assumptions [5] amounts to 50\%. Therefore, technical potential refers to the part of collected calorie waste that is disposed of through storage and which constitute potential input material for effective energy recovery. 


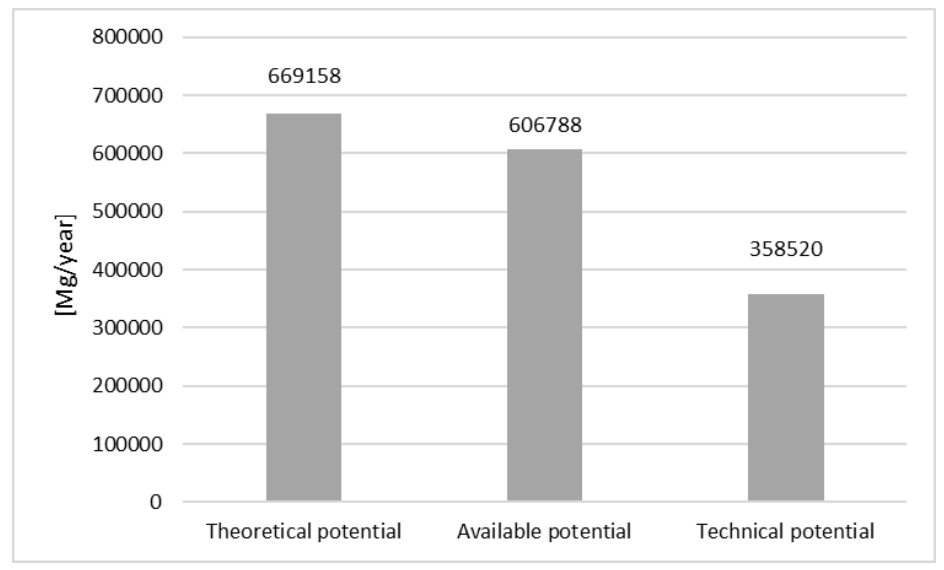

Fig. 2. Energetic potential of wastes in MWMR 2. Source: own elaboration.

\section{Conclusion}

Analysis of the waste management system with the use of value stream mapping allows us to graphically present the flow between the main parts of the system. The ability to single out a selected stream of waste as well as assign it with a value (energetic or material) allows us to pinpoint and eliminate wastage in terms of wastes' unused potential. A strong point of this method is the reduction of flow time and minimisation of reserves. An attempt at transposing the method onto the area of waste management increases the role of recycling and disposal, which affects the efficiency of the waste management system. Presenting the energetic potential lost by disposing of the wastes at the landfill sets out the possible courses of improvement action and modifications to the system.

Creating maps allows us to concentrate implementation efforts on the areas that require a more detailed analysis and improvement. In the case of waste management we can consider streams of a selected group of wastes in the entire system through quantitative and qualitative presentation of flows from the place of origin to the place of recycling/disposal. Additionally, the cataloguing of the system's infrastructure allows us to present the unused processing power in the system or lack thereof.

After identifying selected aspects connected with the functioning of the $2^{\text {nd }}$ MWMR it is recommended that technology allowing for managing high-calorie wastes be implemented into the system. Introducing new technologies for the retrieval of energy from wastes can significantly contribute to reducing the mass of combustible wastes deposited in landfills. The qualitative analysis of combustible wastes gathered confirmed the unused energetic potential and the validity of further research on the effectiveness of implementing a thermal waste processing facility in the $2^{\text {nd }}$ MWMR. Finding the matching efficiency and determining the optimal location for such a facility will allow for increasing the systems efficiency, taking into account the economic, ecological and social circumstances.

This article was prepared within the statutory research titled "Methods and tools for improving products and services on the selected examples" work symbol 13/030/BK_17/0027 performed at Silesian University of Technology, Institute of Production Engineering. 


\section{References}

1. M. Rother, J. Shook, Learning To See - Value Stream Mapping to Create Value and Eliminate Muda (Lean Enterprise Institute, Brookline, MA, 1999)

2. Value stream (http://logistyczny.com/biblioteka/kaizen-lean/item/893-strumienwartosci - 22.02.2017) (in Polish)

3. M. Zasadzień, Z. Nawrot, Manage. Syst. Prod. Eng. 4 (2016)

4. K. Midor, G. Klimasara, Syst. Wspomag. Inż. Prod. 4 (2016)

5. K. Jąderko, B. Białecka, Technological-logistic model of energy utilization process of waste (P.A.NOVA, Gliwice 2016) (in Polish)

6. Act of 14 December 2012 on waste from 2012 (Journal of Laws of the Republic of Poland from 2013 item 21) (in Polish)

7. Regulation of the Minister of Economy of 8 January 2013 on the criteria and procedures for the acceptance of waste for disposal at a landfill of a type (Journal of Laws of the Republic of Poland from 2013 item 38) (in Polish)

8. Waste management plan for Silesian Voivodship 2014 (in Polish) (annex to the resolution of the Silesian Regional Assembly No. IV / 25/1/2012 of 24 August 2012)

9. R. Zarzycki (ed.), Energy from waste (Polska Akademia Nauk, Łódź, 2008) (in Polish)

10. K. Skalmowski (ed.), Waste management guide (Verlag Dashofer, Warszawa, 2010) (in Polish)

11. J. Wandrasz, A. Wandras, Formed fuels (Seidel-Przywecki, Warszawa, 2006) (in Polish)

12. Directive 2010/75/EU of the European Parliament and of the Council of 24 November 2010 on industrial emissions (integrated pollution prevention and control) (in Polish) 